\title{
Peningkatan Keterampilan Menulis Pidato Persuasif Menggunakan Model Problem Based Learning Berbantuan Multimedia bagi Siswa SMP Negeri 2 Mataram
}

\author{
Sahra \\ SMP Negeri 2 Mataram, Kota Mataram - Provinsi NTB \\ *Corresponding Author. Email: sahra15041964@gmail.com
}

\begin{abstract}
This study aims to improve the skills of writing persuasive speech texts by using a multimedia-assisted Problem Based learning model for grade 9J students of SMP Negeri 2 Mataram. This research method used classroom action research. Data were obtained by using field notes, observations, tests, and documentation in the form of assignments. The data analysis technique in this research is descriptive analysis. The results of this study indicate that the application of the Problem Based Learning model assisted by multimedia can increase the activeness of students in learning to write persuasive speech texts. The increase can be seen from the percentage of activeness of $65.71 \%$ in the first cycle to $94.29 \%$ in the second cycle. In addition, the multimedia-assisted Problem Based Learning model can improve the skills of writing persuasive speech texts. This can be seen from the writing results of students who achieved the KKM in the first cycle of $74.29 \%$, increasing to $100 \%$.
\end{abstract}

\begin{abstract}
Abstrak: Penelitian ini bertujuan untuk meningkatkan keterampilan menulis teks pidato persuasif dengan menggunakan model Problem Based learning berbantuan multimedia bagi siswa kelas 9J SMP Negeri 2 Mataram. Metode penelitian ini menggunakan penelitian tindakan kelas. Data diperoleh dengan menggunakan catatan lapangan, observasi, tes, dan dokumentasi berupa tugastugas. Teknik analisis data dalam penelitian ini adalah analissis deskriptif. Hasil penelitian ini menunjukkan bahwa penerapan model Problem Based Learning berbantuan multimedia dapat meningkatkan keaktifan peserta didik dalam pembelajaran menulis teks pidato persuasif. Peningkatan dimaksud dapat dilihat dari persentase keaktifan $65,71 \%$ pada siklus I menjadi $94,29 \%$ pada siklus II. Selain itu, model Problem Based Learning berbantuan multimedia dapat meningkatan keterampilan menulis teks pidato persusif. Hal ini dapat dilihat dari hasil menulis peserta didik yang mencapai KKM pada siklus I sebesar 74,29\% meningkat menjadi $100 \%$.
\end{abstract}

\section{Article History}

Received: 10-08-2021

Revised: 29-08-2021

Accepted: 10-09-2021

Published: 05-10-2021

\section{Key Words:}

Problem Based Learning, Writing Persuasive Speech, Skill.

\section{Sejarah Artikel}

Diterima: 10-08-2021

Direvisi: 29-08-2021

Disetujui: 10-09-2021

Diterbitkan: 05-10-2021

\section{Kata Kunci:}

Problem Based Learning, Keterampilan, Menulis Teks Pidato.

How to Cite: Sahra, S. (2021). Peningkatan Keterampilan Menulis Pidato Persuasif Menggunakan Model Problem Based Learning Berbantuan Multimedia bagi Siswa SMP Negeri 2 Mataram. Jurnal Paedagogy, 8(4), 560-572. doi:https://doi.org/10.33394/jp.v8i4.4127

\section{Pendahuluan}

Menulis merupakan kemampuan menggungkapkan gagasan ke dalam bentuk tulisan. Tulisan sebagai hasil dari kegiatan menulis bertujuan untuk: 1) memberitahu informasi kepada pembaca, 2) meyakinkan atau mendesak pembaca akan kebenaran gagasan yang diutarakan, c) menghibur karena mengandung estetika, dan d) mengekspresi perasaan yang kuat dan berapi-api (Susanto, 2016). Keterampilan menulis adalah keterampilan menuangkan ide, gagasan, perasaan dalam bentuk bahasa tulis sehingga pembaca dapat memahami isi tulisan dengan baik. Keterampilan menulis merupakan keterampilan mekanis yang dapat dipelajari dan diperoleh melalui latihan yang intensif (Sahra, 2020; Jayanti, 2020; Sholeh et al., 2021; Meiningsih, 2021). Seseorang dikatakan terampil menulis apabila mampu memahami dan mengaplikasikan proses pegungkapan ide, gagasan, dan perasaan dengan 
memperhatikan struktur dan aspek kebahasaan, ejaan, dan keutuhan (koherensi), kepaduan (kohesi), tujuan, dan sasaran tulisan. Keterampilan ini merupakan salah satu keterampilan berbahasa yang harus dimiliki peserta didik SMP dengan jalan praktik dan banyak latihan untuk berkomunikasi secara tidak langsung dengan orang lain.

Pidato persuasif merupakan teks yang bertujuan untuk mengajak pembaca melakukan hal yang disampaikan penulis. Menurut Sugono (2012) persuasif adalah bersifat membujuk secara halus supaya menjadi yakin. Jadi, dapat disimpulkan bahwa teks pidato persuasif adalah teks yang disusun, untuk mempengaruhi, mengajak, atau membujuk, pendengar mengikuti keinginan penulis. Struktur teks pidato persuasif menurut Santoso, dkk (2020) terdiri atas: 1) Bagian pembuka terdiri atas salam, sapaan, ucapan syukur pada Tuhan, ucapan terima kasih , dan penyampaian tema pidato; 2) Struktur isi dalam pidato persuasif berisi informasi sebagai dasar dalam mengajak pembaca untuk melakukan apa yang diinginkan penulis; 3) Bagian penutup berisi simpulan, ucapan terima kasih, permohonan maaf, dan salam penutup.

Lebih rinci, Arifin dan Tasai (2009) menjelaskan struktur pidato persuasif adalah: 1) Salam pembuka untuk menyapa hadirin; 2) Pendahuluan yang berisi ucapan terima kasih, atau ungkapan kegembiraan atau rasa syukur; 3) Isi pidato ditulis dengan jelas menggunakan Bahasa Indonesia yang baik dan benar dengan gaya bahasa yang menarik; 4) Kesimpulan dari isi pidato supaya mudah diingat oleh hadirin; 5) Harapan yang berisi ajakan kepada pendengar untuk melaksanakan isi pidato; dan 6) Salam penutup.

Peserta didik SMP dituntut mampu menuangkan gagasan, pikiran, arahan, atau pesan secara tertulis. Keterampilan menulis khususnya menulis pidato persuasif lebih banyak disajikan dalam bentuk penugasan dan metode ceramah. Hal tersebut menimbulkan kebosanan peserta didik. Kurangnya pembiasaan menulis peserta didik, sehingga sulit menuangkan gagasan, pikiran, arahan, atau pesan dalam bentuk tulisan. Hal tersebut menjadi salah satu faktor peserta didik kurang terampil dalam menulis.

Berdasarkan hasil pengamatan pada saat pretest, keterampilan menulis pidato peerta didik kelas 9J SMP Negeri 2 Mataram masih belum mencapai Kreteria Ketuntasan Minimal 80. Hal itu dapat dilihat dari hasil teks pidato persuasif peserta didik pada aspek struktur dan kebahasaan. Berdasarkan hal tersebut, salah satu upaya untuk meningkatkan keterampilan menulis pidato Persuasif peserta didik dengan menggunakan model pembelajaran Promlem Based Learning.

Model pembelajaran Problem Based Learning ini menggunakan berbagai kemampuan berpikir peserta didik secara individu maupun kelompok serta lingkungan nyata untuk mengatasi permasalahan sehingga bermakna, relevan, dan kontekstual (Mashudi, dkk 2007; Akbar, 2019; Astiti, 2021). Tujuan Probem Based Learning adalah meningkatkan kemampuan dalam menerapkan konsep-konsep pada permasalahan baru/ pengintegrasian konsep Higher Order Thingking Skill (HOTS), keinginan dalam belajar, mengarahkan belajar diri sendiri, dan keterampilan. Karakteristik Problem Based Learning antara lain: 1) Masalah digunakan pada awal pembelajaran; 2) Masalah yang digunakan adalah masalah dunia nyata yang disajikan secara mengambang; 3) Masalah menuntut persepektif majemuk; 4) Masalah membuat pembelajar tertantang untuk mendapatkan pembelajaran di ranah pembelajaran yang baru; 5) Sangat mengutamakan belajar mandiri; 6) Memanfaatkan sumber pengetahuan yang bervariasi; 7) Pembelajarannya kolaboratif, komunikatif, dan kooperatif; dan 8) Peserta didik menggunakan kemampuan berpikir tingkat tinggi, dalam memecahkan masalah.

Menurut Yew dan Goh (2016) dan Mandasari (2021) model Problem Based Learning melibatkan peserta didik dalam memecahkan masalah yang berhubungan dengan kehidupan 
sehari-hari. Pembelajaran ini disampaikan dengan cara memberikan suatu permasalahan, mengajukan pertanyaan-pertanyaan, memfasilitasi penyelidikan, dan membuka diskusi. Suprijono (2010) mendefinisikan pembelajaran model Problem Based learning berorientasi pada kecakapan siswa memproses informasi. Hal senada ditambahkan Sani (2014) bahwa model Problem Based Learning menekankan konsep-konsep dan informasi yang dijabarkan dari disiplin-disiplin akademik. Permasalahan yang dikaji merupakan permasalahan kontekstual yang ditemukan peserta didik dalam kehidupan. Berdasarkan bebrapa pendapat di atas peneliti menyimpulkan model Problem Based Learning, dimulai dengan peserta didik diberikan masalah-masalah, bekerja dalam kelompok, mencoba memecahkannya dengan pengetahuan yang telah dimiliki, kemudian menemukan informasi-informasi baru yang relevan sebagai solusi.

Adapun tujuan penelitian ini adalah untuk meningkatkan keterampilan menulis pidato persuasif pada siswa kelas 9J SMP Negeri 2 Mataram melalui penerapan model pembelajaran Promlem Based Learning. Selain itu, penelitian ini juga dilakukan untuk mendorong siswa agar lebih aktif dan kreatif dalam proses pembelajaran.

\section{Metode Penelitian}

Penelitian ini menggunakan desain Penelitian Tindakan Kelas (PTK) yang dilaksanakan di SMPN 2 Mataram dengan subyek penelitian kelas 9J. Penelitian dilasanakan pada bulan Juli sampai bulan September 2021. Tindakan yang dilakukan pada saat pelaksanaan kegiatan belajar mengajar teks pidato persuasif dengan frekuensi pembelajaran 1 kali pembelajaran daring dan 1 kali pembelajaran tatap muka dalam satu minggu dengan durasi waktu pembelajaran 80 menit setip kali tatap muka. Instrumen penilaian yang digunakan dalam penelitian ini adalah lembar pengamatan, catatan lapangan, tes, dan dokumentasi. Lembar pengamatan digunakan untuk mengungkapkan aktivitas peserta didik ketika proses pembelajaran menulis teks pidato persuasif di kelas, ketika tindakan dilakukan. Catatan lapangan digunakan untuk mencatat persoalan-persoalan yang menarik. Tes digunakan untuk mengetahui keterampilan menulis teks pidato peserta didik. Dokumentasi digunakan untuk mendokumentasikan proses kegiatan belajar pada peserta didik.

Penelitian ini menggunakan analisis data kualitataif dan kuantitatif. Data kualitatif dianalisis dengan teknik analisis deskriftif yaitu teknik pengolahan data dengan cara menarasikan hasil data kualitataif yang mencakup hasil pengamatan, catatan lapangan, dan tes. Data kuantitatif diperoleh dari hasil tes menulis teks pidato persuasif yang berupa skor kemampuan menulis teks pidato persuasif peserta didik. Data kuantitatif dianalisis dengan menggunakan statistik deskriptif untuk mencari nilai rerata.

Indikator keberhasilan penelitian ini dikelompokkan dalam dua aspek yaitu proses dan hasil. Indikator keberhasilan proses dilihat dari perkembangan proses perubahan seperti perubahan sikap dan perilaku peseta didik terhadap pelajaran dan meningkatnya motivasi peserta didik dalam pembelajaran. Indikator keberhasilan produk didasarkan atas meningkatnya motivasi peserta didik dalam kegiatan menulis teks pidato persuasif menggunakan model Problem Based Learning seperti perubahan hasil belajar peserta didik secara individu maupun secara kelasikal. Indikator ini dilihat dengan cara membandingkan proses sebelum dan sesudah dilakukan tindakan.

\section{Hasil Penelitian dan Pembahasan}

Penelitian ini dilakukan melalui observasi awal untuk mengetahui proses pembelajaran menulis teks pidato persuasif yang dilaksanakan di kelas 9J SMPN 2 Mataram. 
Kondisi yang diteliti yaitu proses dan hasil pembelajaran menulis teks pidato persuasif. Hasil pratindakan dijadikan acuan untuk menentukan tindakan selanjutnya. Pratindakan berupa observasi pembelajaran di dalam kelas menggunakan angket. Dari hasil observasi diketahui kondisi peserta didik dan keadaan kelas pada saat proses pembelajaran menulis teks pidato persuasif.

Berdasarkan pengamatan, selama pembelajaran tahap pratindakan diperoleh hasil peserta didik kurang aktif mengikuti pembelajaran. Permasalahan tersebut terlihat dari sedikitnya peserta didik yang $b$ bertanya dan menjawab pertanyaan guru, namun bertanya dengan teman sebelahnya. Minat peserta didik dalam menulis teks pidato persuasif juga masih rendah. Hal tersebut terjadi karena pesert didik kesulitan dalam menemukan ide, memiliki kosa kata yang terbatas, sehingga tulisan yang dihasilkan belum maksimal. Berdasarkan hasil pengamatan diketahui bahwa sebanyak 11 peserta didik $(31,42 \%)$ aktif selama mengikuti pembelajaran menulis teks pidato persuasif, sedangkan 24 peserta didik $(68,57 \%)$ lainnya kurang aktif.

Dalam pembelajaran menulis teks pidato persuasif, guru menggunakan metode ceramah dan penugasan, belum melibatkan peran aktif peserta didik, sehingga peserta didik diam, sedangkan guru mendominasi pembelajaran. Berdasarkan analisis pada teks pidato persuaasif , diketahui peserta didik yang telah melampaui batas Kriteria Ketuntasan Minimal (KKM) sebanyak 9 orang $(25,71 \%)$, sebanyak 26 orang $(74,29 \%)$ memperoleh nilai di bawah KKM 80. Hasil pratindakan diketahui skor tertinggi menulis teks pidato persuasif adalah 83 , sedangkan terendah 60. Dilihat dari kriteria teks pidato, terdapat $13(37,14 \%)$ yang memenuhi kriteria sedangkan 22 orang $(62,86 \%)$ memenuhi kriteria teks pidato persuasif. Hasil teks pidato persuasif sebelum menggunakan model Problem Based Learning disajikan dalam bentuk tabel berikut ini.

Tabel 1. Hasil Teks Pidato Persuasif Sebelum Menggunakan Model $P B L$

\begin{tabular}{ccc}
\hline Interval & f absolut & f relatif $(\boldsymbol{\%})$ \\
\hline $55-60$ & 3 & $8,57 \%$ \\
$61-65$ & 7 & $20,00 \%$ \\
$66-70$ & 12 & $34,29 \%$ \\
$75-80$ & 4 & $11,43 \%$ \\
$81-90$ & 9 & $25,71 \%$ \\
& & \\
\hline Jumlah & 35 & $100 \%$
\end{tabular}

Hal yang menyebabkan rendahnya keterampilan menulis teks pidato persuasif pada siswa kelas 9J SMPN 2 Mataram, yaitu: 1) Kesulitan memulai menulis; 2) Perbendaharaan kata terbatas; dan 3) Kesulitan mengembangkan gagasan. Berdasarkan hasil observasi awal, peneliti menentukan langkah selanjutnya, menggunakan model Problem Based Learning dalam pembelajaran.

\section{Hasil Tindakan Siklus I \\ Perencanaan}

Tahap perencanaan pada siklus I di antaranya penyusunan Rencana Pelaksanaan Pembelajaran (RPP). Kompetensi Dasar yang digunakan adalah KD 4.4 Menuangkan gagasan, pikiran, arahan, atau pesan dalam pidato (lingkungan hidup, kondisi sosial, dan/atau keragaman budaya) secara lisan dan/atau tulis dengan memperhatikan struktur dan aspek kebahasaan. Guru merumuskan indikator sebagai berikut: 1) Peserta didik memahami struktur pembukaan, isi, dan penutup teks pidato persuasif; 2) Peserta didik memahami aspek 
kebahasaan teks pidato persuasif; 3) Peserta didik memahami langkah-langkah menulis teks pidato persuasif; 4) Peserta didik mampu mengembangkan kerangka teks pidato Persuasif dengan memperhatikan struktur dan aspek kebahasaan; 5) Peserta didik mampu menentukan judul yang sesuai berdasarkan tema; 6) Peserta didik mampu menyunting teks pidato persuasif sehingga sesuai kreteria standar. Peneliti selanjutnya mempersiapkan instrumen penelitian berupa lembar observasi, tes, pedoman penskoran, kriteria penilaian, serta alat dokumentasi.

\section{Pelaksanaan}

Tahap pelaksanaan pembelajaran menulis teks pidato persuasif siklus I dilaksanakan dua kali pertemuan, menggunakan model Problem Based Learning dengan langkah-langkah sebagai berikut:

a) Pertemuan Pertama

Deskripsi pelaksanaan siklus I pertemuan pertama:

1) Guru menyampaikan Kompetensi Dasar pembelajaran menggunakan metode ceramah dengan mengaitkannya dalam kehidupan, agar peserta didik memiliki gambaran yang akan dipelajari.

2) Guru mengajukan pertanyaan tentang teks pidato persuasif untuk mengetahui penegetahuan awal peserta didik.

3) Guru menjelaskan PPT pengertian, struktur, aspek kebahasaan, langkah-lngkah menulis pidato persuasif, dan syarat judul teks..

4) Guru bersama-sama peserta didik mendiskusikan hal-hal berikut: 1) Langkahlangkah menulis teks pidato persuasif berdasarkan tema: Pandemi Covid-19; 2) Menentukan isi pokok pidato berdasarkan tema dari berbagai sumber; 3) Menyusun kerangka karangan; 4) Mengembangkan kerangka karangan; 5) Menentukan kesesuaian judul dengan tema; 6) Menyunting teks pidato agar sesuai kreteria standar.

5) Guru menajikan teks pidato persuasif bertema Pandemi Covid-19 disertai identifikasi struktur, aspek kebahasaan, dan kesesuaian judul dengan tema untuk diamati peserta didik.

6) Guru menyajikan tema Covid-19, selanjutnya peserta didik secara berkelompok mendiskusikan antara lain: 1) Menentukan isi pokok teks pidato persuasif; 2) Menyusun kerangka teks pidato persuasif; 3) Menentukan materi pengembangan kerangka teks pidato persuasif menggunakan refrensi yang bervariasi; 4) Mengembangkan kerangka teks pidato persuasif; 6) Menentukan kesesuaian judul dengan tema; 7) Menyunting teks pidato persuasif; 8) Mempresentasikan hasil kerja kelompok di depan kelas.

7) Guru bersama-sama peserta didik lain memberi tanggapan pada aspek struktur, kebahasaan, dan kesesuaian judul dengan tema.

8) Guru menugaskan peerta didik menulis teks pidato persuasif secara individu dengan memperhatikan langkah-langkah, struktur, aspek kebahasaan, dan kesesuaian judul dengan tema.

b) Pertemuan Kedua

Pertemuan kedua pada siklus I guru melakukan hal-hal sebagai berikut:

1) Guru mengawali pembelajaran dengan menagih tugas yang diberikan pada pertemuan sebelumnya, yakni teks pidato persuasif bertema Pandemi Covid-19 untuk didiskusikan dalam kelompok pada aspek antara lain: 1) Kesesuaian langkah-langkah menulis teks pidato persuasif; 2) Isi pokok sesuai tema; 3) Kerangka teks pidato; 4) 
Kesesuaian pengembangan teks pidato persuasif dengan tema; 5) Kesesuaian judul dengan tema; 6) Presentasi hasil diskusi di depan kelompok lain; dan 7) Memberi tanggapan atas presentasi individu.

2) Guru bersama peserta didik membahas secara bersama-sama langkah-langkah menyusun pidato persuasif berdasarkan tema pada aspek struktur antara lain: 1) Pembuka yang terdiri dari salam, sapaan, ucapan syukur pada Tuhan, ucapan terima kasih pada yang hadir, dan penyampaian tema pidato persuasif ; 2) Struktur isi terdiri dari 2 kalimat isu, 4 kalimat rangkaian argumen, 2 kalimat ajakan, dan 2 kalimat simpulan; 3) Kesesuaian judul dengan tema yang singkat, jelas, menearik, dan mencerminkan isi pidato persuasif.

3) Guru menyampaikan Kompetensi Dasar dan tujuan pembelajaran yang akan dilaksanakan pada pertemuan kedua teks pidato persuasif menggunakan model Problem Based Learning. berbantuan media gambar.

4) Guru menyiapkan 35 buah permen 7 jenis permen yang rasanya berbeda. Siswa yang mendapatkan permen yang rasanya sama menjadi anggota kelompoknya beranggotakan 5 siswa dengan nama kelompok Aspirasi, Bestari, Diskusi, Orasi, dan Persuasi.

5) Siswa dalam kelompok disajikan permasalahan melalui gambar-gambar wabah penularan covid-19 yang terjadi di Indonesia. Setiap kelompok mendapatkan 5 gambar tentang wabah penularan covid-19 yang berbeda. Guru mendampingi peserta didik mencermati gambar masalah penularan wabah covid-19. Gambar tersebut menjadi tema untuk menulis teks pidato persuasif. Kegiatan ini merupakan bentuk pengorganisasian untuk penyelidikan.

6) Peserta didik dalam kelompok mendiskusikan penyebab penularan wabah covid-19 yang merebak begitu cepat dan menelan korban jiwa.

7) Peserta didik dalam kelompok mencari solusi penularan wabah covid-19 beserta. Tahap ini peserta didik melaksanakan proses identifikasi.

8) Peserta didik dalam kelompok menyimpulkan temuan penyebab penularan wabah covid-19 dan langkah-langkah pencegahan. kemudian secara individu mengembangkannya menjadi teks pidato persuasif.

9) Peserta didik menentukan isi pokok teks pidato persuasif, mengembangkan kerangka, menentukan judul yang sesuai tema, dan menyunting teks pidato hasil identifikasi menjadi teks pidato yang sesuai kreteria standar.

10) Peserta didik membacakan teks pidato persuasif disertai identifikasi struktur, aspek kebahasaan, dan kesesuaian judul dengan tema di depan kelas.

11) Guru bersama peserta didik mendiskusikan teks pidato persuasif terbaik untuk mengevaluasi proses penyelidikan peserta didik.

12) Guru bersama peserta didik bertanya jawab tentang kesulitan menulis teks pidato persuasif. Diketahui bahwa peserta didik masih kesulitan dalam menentukan judul berdasarkan tema, menentukan isi pokok pidato persuasif, menyusun kerangka teks , mengembangkannya kerangka, serta menyunting teks pidato persuasif agar sesuai struktur, aspek kebasaan, dan kesesuaian judul dengan tema. Hal ini disebabkan oleh masih kurangnya pengetahuan dan pemahaman peserta didik tentang teks pidato persuasif. 


\section{Pengamatan (Observasi)}

Pengamatan selama proses pembelajaran menulis teks pidato persuasif menggunakan model Problem Based Learning berbantuan media gambar penularan wabah covid-19 yang terjadi di Indonesia, yang dipilih oleh guru. Pada hal-hal sebagai berikut:

Pengamatan Guru

Proses pembelajaran menulis teks pidato persuasif menggunakan model Problem Based Learning telah dilaksanakan sesuai tahapan dalam Rencana Pelaksanaan Pembelajaran (RPP). Guru menyiapkan gambar penularan wabah covid-19 yang terjadi di Indonesia sebagai masalah yang harus dipecahkan peserta didik. Guru juga menyiapkan permen yang akan digunakan sebagai media memilih anggota kelompok selanjutnya memeriksa kesiapan belajar peserta didik. Guru memulai pembelajaran dengan berdoa ,melakukan apersepsi, menjelaskan tujuan pembelajaran yaitu menulis teks pidato persuasif dengan memperhatikan struktur aspek kebahasaan, serta kesesuaian judul dengN TEMA. Guru kemudian PPT pengertian, struktur, kaidah kebahasaan, dan syarat judul, langkah-langkah menyusun pidato teks pidato persuasif, menggunakan model Problem Based Learning berbantuan media gambar penularan wabah covid-19.

\section{Pengamatan Keaktifan Peserta Didik}

Pengamatan keaktifan peserta didik didasarkan pada tiga indikator yaitu: 1) Keaktifan peserta didik selama mengikuti pembelajaran; 2) Keaktifan peserta didik pada menulis teks pidato persuasif; dan 3) Kemandirian. Siklus I dilaksanakan dalam 2 pertemuan, diperoleh beberapa perubahan pada keaktifan peserta didik dan keterampilan menulis teks pidato persuasif. Dengan demikian, disimpulkan pembelajaran menulis teks pidato persuasif menggunakan model Problem Based Learning t mengalami peningkatan pada proses maupun hasil, meskipun belum maksimal. Peningkatan tersebut dapat dilihat pada penjelasan berikut:

a) Berdasarkan lembar observasi, keaktifan siswa di dalam mengikuti pembelajaran diperoleh data terdapat 23 siswa $(65,71 \%)$ berpartisipasi aktif dalam pembelajaran dan mendapat peridikat baik, 8 siswa $(22,86 \%)$ cukup aktif dan 4 siswa $(11,43 \%)$ tidak aktif dalam pembelajaran.

b) Berdasarkan teks pidato persuasif siswa, diketahui 26 dari 35 siswa (74,29\%) sudah mampu menulis teks pidato persuasif dengan baik dan telah mencapai nilai Kriteria Ketuntasan Minimal (KKM). Sebayak 9 siswa $(25,71 \%)$ mendapat nilai di bawah KKM. Nilai diperoleh dari keseluruhan aspek yang terdapat dalam pedoman penskoran.

Berdasarkan hasil dari siklus I, dapat diketahui bahwa nilai tertinggi keterampilan menulis teks pidato persuasif kelas 9J SMPN 2 Mataram adalah 92 sedangkan nilai terendah 65. Perolehan nilai menulis teks pidato persuasif peserta didik kelas 9J SMPN 2 Mataram dapat disajikan dalam tabel berikut:

Tabel 2. Nilai Menulis Teks Pidato Persuasif

\begin{tabular}{ccc}
\hline Interval & f absolut & f relatif (\%) \\
\hline $61-65$ & 1 & $2,86 \%$ \\
$66-70$ & 2 & $5,71 \%$ \\
$71-75$ & 2 & $5,71 \%$ \\
$81-90$ & 15 & $42,86 \%$ \\
$91-95$ & 11 & $31,43 \%$ \\
\hline Jumlah & 35 & $100 \%$ \\
\hline
\end{tabular}




\section{Refleksi}

Refleksi tindakkan siklus I berisi hasil pengamatan tindakan yang telah dilakukan. Beberapa masukan sebagai perbaikan pada kegiatan siklus II di antaranya:

a) Keaktifan peserta didik dalam mengikuti pembelajaran belum merata .Masih ada yang bersikap pasif ditandai belum berani bertanya kepada guru.

b) Peserta didik belum biasa menemukan sendiri gagasan untuk menulis teks pidato persuasif karena belum mendapat bimbingan secara menyeluruh.

c) Terdapat beberapa peserta didik yang belum mencapai nilai sesuai Kreteria Ketuntasan Minimal. Hal ini menunjukkan bahwa peserta didik masih kesulitan dalam menulis teks pidato persuasif.

d) Keadaan kelas ramai saat pelaksanaan pembelajaran menulis teks pidato persuasif karena beberapa peserta didik belum memahami cara menulis pidato persuasif yang benar.

Rekomendasi Tindakan Siklus II

a) Guru perlu mendampingi peserta didik yang mengalami kesulitan.

b) Pemberian contoh teks pidato persuasif tidak sesuai jumlah kelompok.

c) Guru memberikan contoh teks pidato persuasif beserta analisis struktur, kebahasaan, dan kesesuaian judul dengan tema.

d) Guru bersama siswa menganalisis struktur, aspek kebahasaan, dan kesesuain judul dengan tema teks pidato persuasif yang dibaca.

e) Pada siklus II media gambar yang digunakan diganti dengan media audio visual berupa video.

\section{Hasil Tindakan Siklus II \\ Perencanaan}

Tahap perencanaan pada siklus II diawali dengan penyusunan Rencana Pelaksanaan Pembelajaran (RPP). Kompetensi Dasar yang digunakan adalah KD 4.4 Menuangkan gagasan, pikiran, arahan atau pesan dalam pidato (lingkungan hidup, kondisi sosial, dan/atau keragaman budaya) secara lisan dan/atau tulis dengan memperhatikan struktur dan aspek kebahasaan. Guru merumuskan indikator sebagai berikut: 1) Peserta didik memahami struktur pembuka, isi, dan penutup teks pidato persuasif; 2) Peserta didik mampu menulis teks pidato persuasif sesuai struktur, pola pengembangan, aspek kebahasaan, dan kesesuaian judul dengan tema; dan 3) Peserta didik memperoleh hasil yang meningkat mencapai rata-rata sesuai Kreteria Ketuntasan Minimal sebesar 80. Penggunaan media gambar seperti pada siklus I, kurang merangsang peserta didik untuk menemukan ide . Pada siklus II pertemuam I kegiatan dilakukan secara kelompok dan pertemuan ke-2 dilakukan secara individu.

\section{Pelaksanaan}

Pelaksanaan siklus II dilakukan dalam dua pertemuan dengan kegiatan sebagai berikut:

1) Guru memulai pebelajaran dengan menyampaikan Kompetensi Dasar, tujuan pembelajaran, dan apersepsi menggunakan metode ceramah. Pada pertemuan pertama siklus II ini, seluruh peserta didik menulis teks pidato persuasif menggunakan model Problem Based Learning berbantuan media video prosesi pemakaman korban covid19.

2) Guru mengulas teks pidato peserta didik pada pertemuan pertama siklus II. Teks pidato peserta didik belum maksimal karean aspek struktur, kebahasaaa, dan kesesuaian judul dengan tema belum disajikan sesuai kreteria. 
3) Guru menanyakan kesulitan peserta didik dalam menulis teks pidato persuasif. Data kesulitan pesert didik sebagai berikut: 1) Menentukan tema; 2) Menentukan isi pokok pidato; 3) Menyusun kerangka pidato; 4) Mengumpulkan refrensi yang dibutuhkan dari berbagai sumber; 5) Mengembangkan kerangka; 6) Menentukan judul berdasarkan team; dan 7) Menyunting teks pidato agar struktur, aspek kebahsaan, dan kesesuaian judul dengan tema.

4) Guru menayangkan contoh teks pidato pidato persuasif melalui proyektor.

5) Guru menanyakan kesulitan peserta didik dalam menulis teks pidato persuasif.

6) Guru menjelaskan kegiatan pada siklus II, yaitu menulis teks pidato persuasif berbantuan video prosesi pemakaman korban covid-19 yang terjadi di Indonesia.

7) Guru menayangkan video prosesi pemakaman korban covid-19 untuk memberi orientasi permasalahan yang harus dipecahkan.

8) Guru mendampingi pesrta didik selama penayangan video prosesi pemakaman korban covid-19, berdurasi 4 menit yang ditayangkan 3 kali. Hal tersebut merupakan langkah mengorganisasikan peserta didik dalam penyelidikan.

9) Peserta didik mencermati tayangan video prosesi pemakaman korban covid-19, sambil mengidentifikasi penyebab penularan virus covid-19 serta tindakan protokol kesehatan yang harus dilakukan agar dapat meminimalisir korban jiwa. Kegiatan ini merupakan tahap pelaksanaan identifikasi.

10) Peserta didik menyusun kerangka teks pidato persuasif dengan bantuan lembar kerja yang telah disiapkan guru.

11) Peserta didik mengembangkan kerangka teks pidato persuasif menjadi teks pidato persuasif yang sesuai struktur, aspek kebahasaan, dan keseuaian judul dengan tema. Pola ini merupakan pengembangan hasil identifikasi peserta didik.

12) Guru memberi kesempatan peserta didik membacakan hasil di depan kelas sebagai bentuk penyajian hasil identifikasi.

13) Guru bersama peserta didik mendiskusikan teks pidato persuasif, kemudian menentukan teks terbaik untuk mengevaluasi proses penyelidikan dan memberi apresiasi.

14) Guru mengulas kembali pembelajaran menulis teks pidato persuasif, melakunan tanya jawab, dan bersama peserta didik menyampaikan simpulan pembelajaran.

\section{Pengamatan (Observasi)}

Pengamatan dilakukan selama pembelajaran menulis teks pidato persuasif menggunakan model Problem Based Learning berbantuan media video prosesi pemakaman korban covid19 yang telah dipilih guru. Siklus II dilaksanakan dalam dua kali pertemuan. Hal-hal yang dilakukan dalam pengamatan adalah:

\section{Pengamatan Guru}

Proses pembelajaran menulis teks pidato persuasif menggunakan model Problem Based Learning telah dilaksanakan sesuai tahapan dalam Rencana Pelaksanaan Pembelajaran (RPP). Guru menyiapkan alat bantu pembelajaran seperti laptop, speaker, dan LCD, untuk menayangkan video prosesi pemakaman korban covid-19 yang terjadi di Indonesia. Video berfungsi sebagai media juga sebagai permasalahan yang harus dipecahkan oleh peserta didik. Melalui video, peserta didik ditugaskan menulis kerangka teks pidato persuasif kemudian menegmabngkan ke dalam teks pidato persuasif yang sesuai kreteria standar.

Pengamatan Keaktifan Peserta Didik 
Pengamatan keaktifan peserta didik didasarkan pada tiga indikator adalah: 1) Keaktifan peserta didik selama mengikuti pembelajaran; 2) Keaktifan peserta didik pada saat menulis teks pidato persuasif; dan 3) Kemandirian.

Berdasarkan lembar observasi, keaktifan menulis teks pidato persuasif peserta didik diperoleh data 33 siswa $(94,29 \%)$ aktif, 2 siswa $(5,71 \%)$ belum aktif, sementara 1 siswa $(2,86 \%)$ tidak aktif dalam pembelajaran. Berdasarkan hasil menulis teks pidato persuasif peserta didik, diketahui 35 siswa sudah mampu mencapai Kriteria Ketuntasan Minimal (KKM). Hal ini menunjukkan bahwa keseluruhan peserta didik (100\%) sudah terampil menulis teks pidato persuasif. Berdasarkan hasil pada siklus II, diketahui bahwa nilai tertinggi keterampilan menulis teks pidato persuasif peserta didik kelas 9J SMPN 2 Mataram adalah 97 sedangkan nilai terendah 82.Perolehan nilai menulis teks pidato persuasif peserta didik kelas 9J SMPN 2 Mataram dapat disajikan dalam tabel berikut.

Tabel 3. Nilai Menulis Teks Pidato Persuasif

\begin{tabular}{ccc}
\hline Interval & f absolut & f relatif (\%) \\
\hline $80-84$ & 14 & $40.00 \%$ \\
$85-89$ & 10 & $28,57 \%$ \\
& & \\
$90-94$ & 6 & $17,14 \%$ \\
$95-100$ & 5 & $14,29 \%$ \\
\hline Jumlah & 35 & $100 \%$ \\
\hline
\end{tabular}

\section{Refleksi}

Refleksi tindakkan siklus II ini berisi hasil pengamatan tindakan kelas yang telah dilakukan. Diperoleh beberapa hal sebagai berikut:

1) Pembelajarn pada siklus II lebih baik jika dibandingkan dengan siklus I. Hal ini dapat dilihat dari meningkatnya hasil nilai rata-rata peserta didik.

2) Keaktifan peserta didik selama kegiatan pembelajaran menulis teks pidato persuasif sudah merata. Suasana kelas kondusif, dapat dilihat dari tidak adanya peserta didik yang melakukan aktivitas yang tidak berhubungan dengan pembelajaran. Di samping itu, peserta didik sudah berani bertanya dan aktif di kelas karena pembelajaran pada siklus II ini menyenangkan.

3) Ide dan gagasan peserta didik muncul dan berkembang karena rangsangan yang diberikan oleh guru tepat dan maksimal.

Secara garis besar penelitian yang telah dilakukan pada dua siklus menggunakan model Problem Based Learning dalam menulis teks pidato persuasif berjalan lancar sesuai rencana. Keaktifan peserta didik mengalaami peningkatan. Peserta didik merespon kegiatan pembelajaran dalam dua pertemuan dengan baik. Kekurangan yang terjadi pada siklus I telah diatasi pada siklus II. Secara kualitas, keterampilan menulis teks pidato persuasif peserta didik menunjukkan peningkatan. Seluruh peserta didik telah mencapai KKM. Hal ini ini menunjukkan bahwa model Problem Based Learning membantu peserta didik dalam proses pembelajaran menulis teks pidato persuasif. Pada siklus II, proses dan hasil pembelajaran menulis teks pidato persuasif meningkat dibandingkan dengan siklus I. Keaktifan dan keterampilan menulis teks pidato persuasif telah meningkat. Pada Indikator penilaian menunjukkan hasil yang memuaskan.

Berdasarkan hasil pengamatan (observasi) dan hasil analisis, data yang diperoleh telah terjadi peningkatan keaktifan dan keterampilan peserta didik dalam pembelajaran menulis teks pidato persuasif menggunakan model Problem Based Learning berbantuan media gambar pada siklus I. Terdapat sebagian peserta didik yang tidak menunjukkan keaktifan 
dalam pembelajaran. Keaktifan peserta didik selama mengikuti pembelajaran meliputi keaktifan merespon seperti menanggapi, bertanya, dan menjawab pertanyaan guru. Konsentrasi selama mengikuti pembelajaran ditunjukkan dengan tidak berbicara dengan teman serta tidak melakukan aktivitas lain yang tidak berhubungan dengan pembelajaran. Keaktifan peserta didik dalam menulis teks pidato persuasif menggunakan model Problem Based Learning berbantuan media gambar. Dari 35 peserta didik pada siklus I hanya 23 $(65,71 \%)$ yang mendapat predikat baik dan aktif selama pembelajaran, sedangkan 8 peserta didik $(22,86 \%)$ cukup aktif, dan 4 peserta didik $(11,43 \%)$ kurang aktif selama pembelajaran. Pada siklus I menunjukkan bahwa 26 peserta didik (74,29\%) dari 35 peserta didik mencapai batas Kriteria Ketuntasan Minimal (KKM), sementara 9 peserta didik $(25,71 \%)$ belum tuntas KKM. Menurut hasil analisis, peserta didik masih kesulitan mengembangkan gagasan. Permasalahan ini kemudian dicari solusinya dan diperbaiki pada siklus II.

Berdasarkan data di atas, diketahui bahwa prosentase yang telah diraih pada siklus I dan siklus II menunjukkan adanya peningkatan pada kedua indikator. Indikator pertama yaitu keaktifan peserta didik selama mengikuti pembelajaran menulis teks pidato persuasif telah meningkat sebesar 28,58\%. Pada indikator kedua yaitu aspek ketuntasan hasil belajar menulis teks pidato persuasif juga mengalami peningkatan sebesar $25,71 \%$. Guru telah berhasil melaksanakan pembelajaran menulis teks pidato persuasif menggunakan model Problem Based Learning berbantuan multimedia. Pembelajaran dengan model Problem Based Learning berbantuan multimedia dapat merangsang peserta didik untuk menemukan gagasan dalam menulis teks pidato persuasif, sehingga hasilnya meningkat. Selain itu, model Problem Based Learning berbantuan multimedia dapat meningkatkan keaktifan peserta didik dalam mengikuti pembelajaran, sehingga keterampilan menulis teks pidato persuasif peserta didik pun meningkat. Berikut ini adalah grafik peningkatan kualitas proses pembelajaran menulis teks pidato persuasif dengan menggunakan model Problem Based Learning berbantuan multimedia pada peserta didik kelas 9J SMPN Mataram.

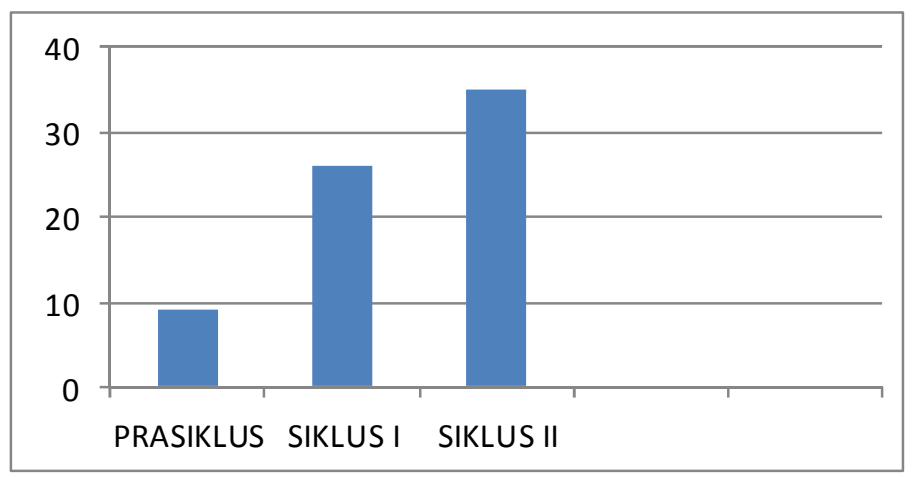

\section{Gambar 1.Grafik Ketuntasan Keterampilan Menulis Teks Pidato Persuasif}

Keterangan:

1) Pada prasiklus (pratindakan) peserta didik yang mencapai KKM sebanyak 9 siswa $(25,71 \%)$ dari 35 peserta didik.

2) Siklus I peserta didik yang mencapai KKM $26(74,29 \%)$ dari 35 peserta didik.

3) Siklus II seluruh peserta didik telah mencapai KKM (100\%)

\section{Pembahasan}

Penelitan peningkatan keterampilan menulis teks pidato persuasif menggunakan model problem based learning berbantuan multimedia pada peserta didik kelas 9J SMPN 2 
Mataram tahun pelajaran 2021-2022, telah berhasil dilaksanakan. Berdasarkan data observasi, keaktifan peserta didik pada tiap siklus menunjukkan peningkatan. Pada siklus I peserta didik yang aktif selama pembelajaran sebesar $65,71 \%$ meningkat menjadi $94,29 \%$ pada siklus II. Selama pembelajaran peserta didik menjadi aktif dan tertarik yang dibuktikan dengan respon peserta didik terhadap pembelajaran seperti bertanya, menjawab, dan menanggapi penjelasan guru. Peningkatan keaktifan dan keterampilan menulis teks pidato persuasif terjadi karena guru telah menggunakan model dan media yang merangsang siswa aktif selama pembelajaran dan pembelajaran tidak lagi berpusat pada guru.

Kualitas menulis teks pidato persuasif dengan menggunakan model Problem Based Learning berbantuan multimedia mengalami peningkatan. Permasalahan ini terlihat dari indikator proses pembelajaran yang mengalami peningkatan pada setiap siklus. Dari hasil penelitian diketahui bahwa proses pembelajaran menulis teks pidato persuasif pada siklus I mencapai 74,29\%, meningkat lebih baik dari prasiklus yang hanya mencapai ketuntasan sebanyak 37,14\%. Dengan demikian, dapat dikatakan bahwa tindakan yang dilakukan guru untuk meningkatkan kualitas proses pembelajaran telah berhasil. Terbukti, pembelajaran menggunakan model Problem Based Learning berbantuan multimedia memiliki peran yang sangat besar dalam meningkatkan kualitas belajar- mengajar.

Penggunaan media gambar dalam pembelajaran model Problem Based Learning pada siklus I berhasil meningkatkan keterampilan menulis teks pidato persuasif peserta didik. Media gambar yang dipilih guru untuk meningkatkan keterampilan menulis teks pidato persuasif telah berhasil dilaksanakan. Peserta didik terbantu karena gagasan yang dimiliki dapat optimal dituangkan dalam teks pidato persuasif. Hal ini sejalan dengan meningkatnya hasil yang diperoleh. Pada siklus II, guru menggunakan media audio visual agar hasil menulis teks pidato persuasif lebih meningkat dari siklus I. Media audio visual sangat menarik perhatian peserta didik dalam menulis teks pidato persuasif.

\section{Kesimpulan}

Kesimpulan yang diperoleh dari hasil penelitian ini adalah penerapan model Problem Based Learning berbantuan multimedia dapat meningkatkan keaktifan peserta didik dalam pembelajaran menulis teks pidato persuasif. Peningkatan dimaksud dapat dilihat dari persentase keaktifan $65,71 \%$ pada siklus I menjadi $94,29 \%$ pada siklus II. Selain itu, model Problem Based Learning berbantuan multimedia dapat meningkatan keterampilan menulis teks pidato persusif. Hal ini dapat dilihat dari hasil menulis peserta didik yang mencapai KKM pada siklus I sebesar 74,29\% meningkat menjadi $100 \%$.

\section{Saran}

Saran yang disampaikan berdasarkan hasil penelitian ini adalah; (1) Guru seyogyanya selalu berusaha mengimplementasikan model-model pembelajaran yang inovatif dan menerapkan teknik-teknik yang sesuai seperti model Problem Based Learning dalam pembelajaran menulis teks pidato persuasif; dan 2) Guru seyogyanya selalu mencoba menerapkan berbagai model pembelajaran dengan teknik-teknik pembelajaran yang unik untuk meningkatkan hasil pembelajaran.

\section{Daftar Pustaka}

Alwi, dkk. (2010). Tata Bahasa Baku Bahasa Indonesia. Jakarta: Balai Pustaka.

Akbar, A. (2019). Implementasi Model Pembelajaran Berbasis Masalah untuk Meningkatkan Hasil Belajar Siswa pada Mata Pelajaran PKn di SMA Negeri 1 Batukliang 
Utara. Jurnal Kependidikan: Jurnal Hasil Penelitian dan Kajian Kepustakaan di Bidang Pendidikan, Pengajaran dan Pembelajaran, 5(1), 1-7. doi:https://doi.org/10.33394/jk.v5i1.1386

Arifin, Zaenal dan S. Amran Tasai. (2009). Cermat Berbahasa Indonesia untuk Perguruan Tinggi sebagai Mata Kuliah Pengembangan kepribadian (MPK). Jakarta: Akademia Pressindo.

Astiti, J., Subekti, E., \& Kuswandari, K. (2021). Peningkatan Hasil Belajar Siswa pada Tema 7 Perkembangan Teknologi Melalui Model Pembelajaran Problem Based Learning di Kelas III SDN Karangreja 01 Kabupaten Brebes. Jurnal Paedagogy, 8(3), 357363. doi:https://doi.org/10.33394/jp.v8i3.3901

Amri, S. \& Ahmadi, I.K. (2014). Proses Pembelajaran Kreatif dan Inovatif dalam Kelas. Jakarta: PT. Prestasi Pustakaraya.

Jayanti, F., \& Fachrurazi, F. (2020). Peningkatan Keterampilan Menulis Karangan Deskripsi Melalui Metode Discovery dengan Menggunakan Media Gambar pada Mahasiswa Program Studi Pendidikan Bahasa dan Sastra Indonesia STKIP Pontianak. Jurnal Kependidikan: Jurnal Hasil Penelitian dan Kajian Kepustakaan di Bidang Pendidikan, Pengajaran dan Pembelajaran, 6(2), 329-339. doi:https://doi.org/10.33394/jk.v6i2.2491

Mahsun. (2013). "Pembelajaran Bahasa Indonesia Menggunakan Pendekatan Teks". Kompas Edu. 27 Februari 2013.

Mandasari, N. (2021). Penerapan Model Pembelajaran Berbasis Masalah Berbantuan Media Power Point untuk Meningkatkan Aktivitas dan Hasil Belajar Siswa di SDN Pandean Lamper 02 Semarang. Jurnal Paedagogy, 8(3), 328-337. doi:https://doi.org/10.33394/jp.v8i3.3886

Meiningsih, S. (2021). Rolling Ball - Learning Cell dalam Pembelajaran untuk Meningkatkan Keterampilan Menulis Bahasa Inggris Siswa. Jurnal Paedagogy, 8(2), 190-196. doi:https://doi.org/10.33394/jp.v8i2.3511

Purwaningrum, S.W. (2013). Penggunaan Metode Peta Pikiran (Mind Mapping) untuk Meningkatkan Kemampuan Menulis Narasi Siswa Sekolah Menengah Pertama. BASASTRA Jurnal Penelitian Bahasa Sastra Indonesia dan Pengajarannya, 2(1), 113.

Sahra, S. (2020). Peningkatan Keterampilan Menulis Kreatif Puisi Bebas Melalui Media Batu bagi Siswa SMPN 15 Mataram. Jurnal Paedagogy, 7(4), 330-338. doi:https://doi.org/10.33394/jp.v7i4.2892

Sani, R.A. (2014). Pembelajaran Saintifik untuk Implementasi Kurikulum 2013. Jakarta: Bumi Aksara.

Sholeh, A., Veryliana, V., \& Darsimah, D. (2021). Meningkatkan Keterampilan Menulis Deskripsi dengan Model Picture and Picture di SDN 3 Bangkleyan Kabupaten Blora. Jurnal Paedagogy, 8(3), 454-459. doi:https://doi.org/10.33394/jp.v8i3.3910

Sugono, Dendy, dkk. (2012). Kamus Besar Bahasa Indonesia (KBBI) edisi keempat. Gramedia, Jakarta.

Suprijono, A. (2010). Cooperative Learning: Teori dan Aplikasi PAIKEM. Yogyakarta: Pustaka Pelajar.

Warsono dan Hariyanto. (2013). Pembelajaran Aktif. Bandung: Remaja Rosdakarya.

Yew, E.H., \& Goh, K. (2016). Problem Based Learning: an overview of its process and inpact on learning. Healt Professions Education, 2(2), 75-79. 